Article

\title{
Synthesis of Chromium Carbide Nanopowders by Microwave Heating and Their Composition and Microstructure Change under Gamma Ray Irradiation
}

\author{
Kai Jin, Yuanbo Jia, Zhiwei Zhao *, Weiqiang Song, Shun Wang and Chunlong Guan \\ College of Materials Science and Engineering, Henan University of Technology, Henan 450001, China; \\ 13298191127@163.com (K.J.); 15649856931@163.com (Y.J.); weiqiang_song@haut.edu.cn (W.S.); \\ shun_wang@haut.edu.cn (S.W.); chunlong_guan@haut.edu.cn (C.G.) \\ * Correspondence: zhiwei_zhao@haut.edu.cn; Tel.: +86-371-6775-8734 \\ Academic Editor: John Spencer \\ Received: 3 November 2018; Accepted: 16 December 2018; Published: 20 December 2018 \\ check for \\ updates
}

\begin{abstract}
Chromium carbide nanopowders were synthesized by mechanical alloying-assisted microwave heating. The effect of gamma irradiation on phase composition and microstructure of chromium carbide nanopowders synthesized by the microwave heating method was analyzed. The samples were characterized by X-ray diffractometry (XRD), X-ray photoelectron spectroscopy (XPS), scanning electron microscopy (SEM), transmission electron microscopy (TEM), and high-resolution transmission electron microscopy (HRTEM) techniques. The results showed that well-dispersed chromium carbide nanopowders can be synthesized by maintaining the temperature at $1000{ }^{\circ} \mathrm{C}$ for $1 \mathrm{~h}$. Gamma ray irradiation had an important effect on the microstructure of chromium carbide nanopowders. The interplanar spacings of chromium carbide (110) crystal faces before and after gamma ray irradiation were $0.3725 \mathrm{~nm}$ and $0.3824 \mathrm{~nm}$, respectively. The crystal structure of chromium carbide was changed by gamma ray irradiation. Gamma ray irradiation can also increase the binding energy of chromium carbide, which is beneficial to improve the thermal stability and mechanical properties of chromium carbide at high temperature.
\end{abstract}

Keywords: microwave heating; gamma irradiation; HRTEM; microstructure; chromium carbide

\section{Introduction}

The transition metal carbides have attractive mechanical properties (e.g., excellent strength, hardness, anti-erosion qualities), outstanding corrosion properties, positive temperature coefficients of resistivity, and permanent non-magnetizability [1]. Chromium carbide $\left(\mathrm{Cr}_{3} \mathrm{C}_{2}\right)$, as a typical representative, demonstrates excellent properties, including high melting point $\left(1810^{\circ} \mathrm{C}\right)$, excellent compressive strength (4.1 GPa [2]), high hardness (Hv, $18 \mathrm{GPa}$ [3]), low density (6.68 g/ $\mathrm{cm}^{3}$ [4]) and good resistance to oxidation, corrosion, and wear. As a result, $\mathrm{Cr}_{3} \mathrm{C}_{2}$ has been widely used in a variety of industrial applications, such as rocket nozzles, shaft seals, shaft bearings, cutting tools, and anticorrosive coating [5-7].

Until now, there have been a number of methods for the preparation of chromium carbides, including direct element reaction, gas reduction-carburization, and conventional carbothermal reduction [8-10]. In the above-mentioned methods, the most commonly used method for synthesizing $\mathrm{Cr}_{3} \mathrm{C}_{2}$ is the carbothermal reduction method using micron-sized chromium oxide and carbon powders as raw materials. However, the process usually requires a high reaction temperature $\left(>1400{ }^{\circ} \mathrm{C}\right)$ and a long reaction time $(20-40 \mathrm{~h})$ [11]. 
Mechanical alloying (MA) has been considered a powerful and practical process for the fabrication of several advanced materials including solid solutions, intermetallic phases, nano-structured materials, and amorphous alloys [12,13]. Microwave heating has become an interesting method for the synthesis of ceramic materials [14]. It generates heat within the material, which then spreads in the entire volume, and can save energy and time [15]. In this paper, $\mathrm{Cr}_{3} \mathrm{C}_{2}$ nanopowders were synthesized by mechanical alloying-assisted microwave heating using micron-sized $\mathrm{Cr}_{2} \mathrm{O}_{3}$ and nano-sized carbon black as raw materials. The direct and fast heating enhanced by the presence of carbon, led to the synthesis of pure carbides in a reduced time, with very crystalline, fine particles presenting excellent and interesting morphology [16].

Nowadays, irradiation (with electrons, ions, gamma rays, etc.) is considered an emerging innovative, valuable tool for modifying the structure of nanomaterials $[17,18]$. Gamma ray irradiation with different strengths is a powerful physical treatment that can produce structural ordering and disordering of nanomaterials [19,20]. Kleut et al. [21] studied the gamma irradiation effects on the structure of single-wall carbon nanotubes (SWCNT). Their results showed that gamma irradiation caused SWCNT covalent functionalization, and the degree of disorder in the carbon nanotube structure correlated with the irradiation dose. Naim et al. [22] reported the effect of gamma irradiation on the mechanical properties of a PVC/ZnO polymer nanocomposite. The results showed that gamma irradiation resulted in a detectable decrease of the elastic modulus for pure and low-weight ratio $\mathrm{ZnO}$ nanoparticles. However, the irradiation dose did not have any effects on the elastic modulus of nanoparticles with a $w \mathrm{t} \%$ ratio of 10 .

Little attention has been paid to the comparison between the effects of irradiation and those of other conditional treatments of carbide nanopowders. In this study, the effect of gamma irradiation on phase composition and microstructure of $\mathrm{Cr}_{3} \mathrm{C}_{2}$ nanopowders was examined for the first time. The results may be helpful to investigate the mechanism of the interaction between gamma ray and carbide materials.

\section{Results and Discussion}

Figure 1 shows the XRD patterns of the powders after mechanical alloying and their microwave synthesis products at $1000{ }^{\circ} \mathrm{C}$ for different carbon contents ( $32 \mathrm{wt} \% \mathrm{C}$ and $34 \mathrm{wt} \% \mathrm{C}$ ). As shown in Figure 1a,b, all peaks were identified as $\mathrm{Cr}_{2} \mathrm{O}_{3}$, while carbon black existed in amorphous form. Furthermore, there were clear signs of peaks broadening, indicating that the particle size of the raw materials became smaller after being milled by the planetary ball mill [23]. This shows that ball milling for a long time did not affect particle composition, while reducing the material diameter. From Figure 1c,d, it can be seen that the product was composed of $\mathrm{Cr}_{3} \mathrm{C}_{2}$ (JCPDS 35-0804), $\mathrm{Cr}_{7} \mathrm{C}_{3}$ (JCPDS 11-0550), and $\mathrm{Cr}_{2} \mathrm{O}_{3}$ (JCPDS 38-1479). This indicated that the oxidation-reduction reaction between $\mathrm{Cr}_{2} \mathrm{O}_{3}$ and carbon was not completed when the carbon content was $32 \mathrm{wt} \% \mathrm{C}$. With the increasing of the carbon content, as shown in Figure 1d, the product was mainly composed of $\mathrm{Cr}_{3} \mathrm{C}_{2}$ (JCPDS 35-0804) and $\mathrm{Cr}_{7} \mathrm{C}_{3}$ (JCPDS 11-0550), indicating that the oxidation-reduction reaction between $\mathrm{Cr}_{2} \mathrm{O}_{3}$ and carbon was completed when the carbon content was $34 \mathrm{wt} \% \mathrm{C}$.

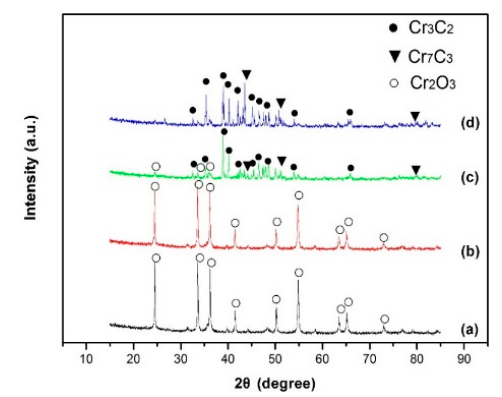

Figure 1. XRD patterns of the powders before and after microwave heating: (a) before microwave heating (32 wt \% C); (b) before microwave heating (34 wt \% C); (c) $1000^{\circ} \mathrm{C}, 1 \mathrm{~h}(32 \mathrm{wt} \% \mathrm{C}) ;$ (d) $1000{ }^{\circ} \mathrm{C}, 1 \mathrm{~h}(34 \mathrm{wt} \% \mathrm{C})$. 
Figure 2 shows the XRD patterns of the powders after mechanical alloying and their microwave synthesis products at $100{ }^{\circ} \mathrm{C}$ for different holding time $(0.5 \mathrm{~h}, 1 \mathrm{~h}, 1.5 \mathrm{~h}$, and $2 \mathrm{~h})$. The insertion is an enlargement of the diffraction peaks of the products at $38-40^{\circ}$. As shown in Figure $2 \mathrm{a}$, all peaks were identified as $\mathrm{Cr}_{2} \mathrm{O}_{3}$ without the carbon phase. In Figure $2 b$, it can be seen that the product was mainly composed of $\mathrm{Cr}_{3} \mathrm{C}_{2}$ (JCPDS 35-0804) and $\mathrm{Cr}_{7} \mathrm{C}_{3}$ (JCPDS 11-0550), indicating that the oxidation-reduction reaction between $\mathrm{Cr}_{2} \mathrm{O}_{3}$ and carbon was completed at $1000{ }^{\circ} \mathrm{C}$ for $0.5 \mathrm{~h}$. With the increase of the holding time, the intensity of the diffraction peaks of $\mathrm{Cr}_{7} \mathrm{C}_{3}$ decreased gradually, while $\mathrm{Cr}_{3} \mathrm{C}_{2}$ it showed the opposite trend (Figure 2c,d). When the holding time reached $2 \mathrm{~h}$, all peaks were identified as $\mathrm{Cr}_{3} \mathrm{C}_{2}$ (Figure 2e), indicating that $\mathrm{Cr}_{7} \mathrm{C}_{3}$ (JCPDS 11-0550) completely transformed into $\mathrm{Cr}_{3} \mathrm{C}_{2}$ (JCPDS 35-0804). In the insertion in Figure 2b,c, it can be seen that the diffraction peaks of $\mathrm{Cr}_{3} \mathrm{C}_{2}$ shifted toward larger angles with the increase of the holding time, which was caused by the crystallization of chromium carbide. As shown in the insertion in Figure 2c-e, the diffraction peaks of $\mathrm{Cr}_{3} \mathrm{C}_{2}$ shifted toward smaller angles with a prolonged holding time. This happened mainly because the crystalline interplanar spacing of $\mathrm{Cr}_{3} \mathrm{C}_{2}$ increased with the increase of the holding time, which led to the decrease of the diffraction angle [23]. As mentioned above, a $\mathrm{Cr}_{3} \mathrm{C}_{2}$ phase with good crystallinity could be synthesized at $1000{ }^{\circ} \mathrm{C}$ for $1 \mathrm{~h}$. The synthesis temperature required by the method here described was at least $400{ }^{\circ} \mathrm{C}$ lower than that of the conventional method $\left(1400{ }^{\circ} \mathrm{C}\right)$ [5]. Furthermore, the synthesis temperature was $100{ }^{\circ} \mathrm{C}$ lower than those of the precursor and carbon thermal reduction methods [24,25].

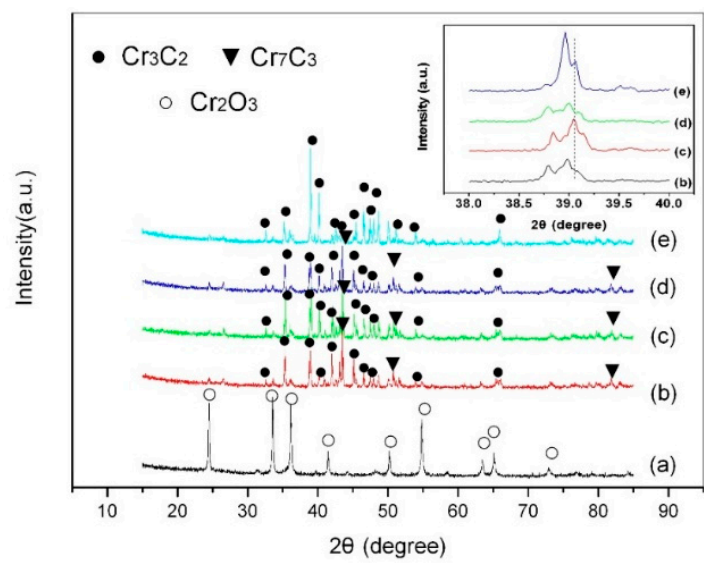

Figure 2. XRD patterns of the powders before and after microwave heating: (a) before microwave heating; (b) $0.5 \mathrm{~h}$; (c) $1 \mathrm{~h}$; (d) $1.5 \mathrm{~h}$; (e) $2 \mathrm{~h}$. The insertion is an enlargement of the diffraction peaks of the products at $38-40^{\circ}$.

Figure 3 shows typical TEM micrographs of the powders after mechanical alloying and their microwave synthesis products at $1000{ }^{\circ} \mathrm{C}$ for different holding time $(0.5 \mathrm{~h}, 1 \mathrm{~h}, 1.5 \mathrm{~h}$, and $2 \mathrm{~h})$.

As shown in Figure $3 \mathrm{a}$, the powders after mechanical alloying showed good dispersion and were mainly composed of particles with a mean diameter of about $50 \mathrm{~nm}$. This was mainly because the particles were constantly impacted and fractured, leading to a considerable reduction of the particle size as a result of the energy provided during ball milling. However, slight agglomeration occurred in the powders as a result of intense mechanical deformation, refinement, and cold welding of particles during mechanical alloying $[10,26]$. When the holding time was $0.5 \mathrm{~h}$, most powders showed good dispersion, and a small amount of particles exhibited the aggregation phenomenon, which might have been caused by the incomplete crystallization of $\mathrm{Cr}_{3} \mathrm{C}_{2}$, as shown in Figure $3 \mathrm{~b}$. When the holding time reached $1 \mathrm{~h}$, the powders showed good dispersion and were mainly composed of spherical or nearly spherical particles with a mean diameter of about $50 \mathrm{~nm}$, as shown in Figure 3c. When the holding time reached $1.5 \mathrm{~h}$ and $2 \mathrm{~h}$, the powders exhibited many agglomerated particles (Figure 3d,e), indicating that longer holding times led to the occurrence of molten particles [25]. 

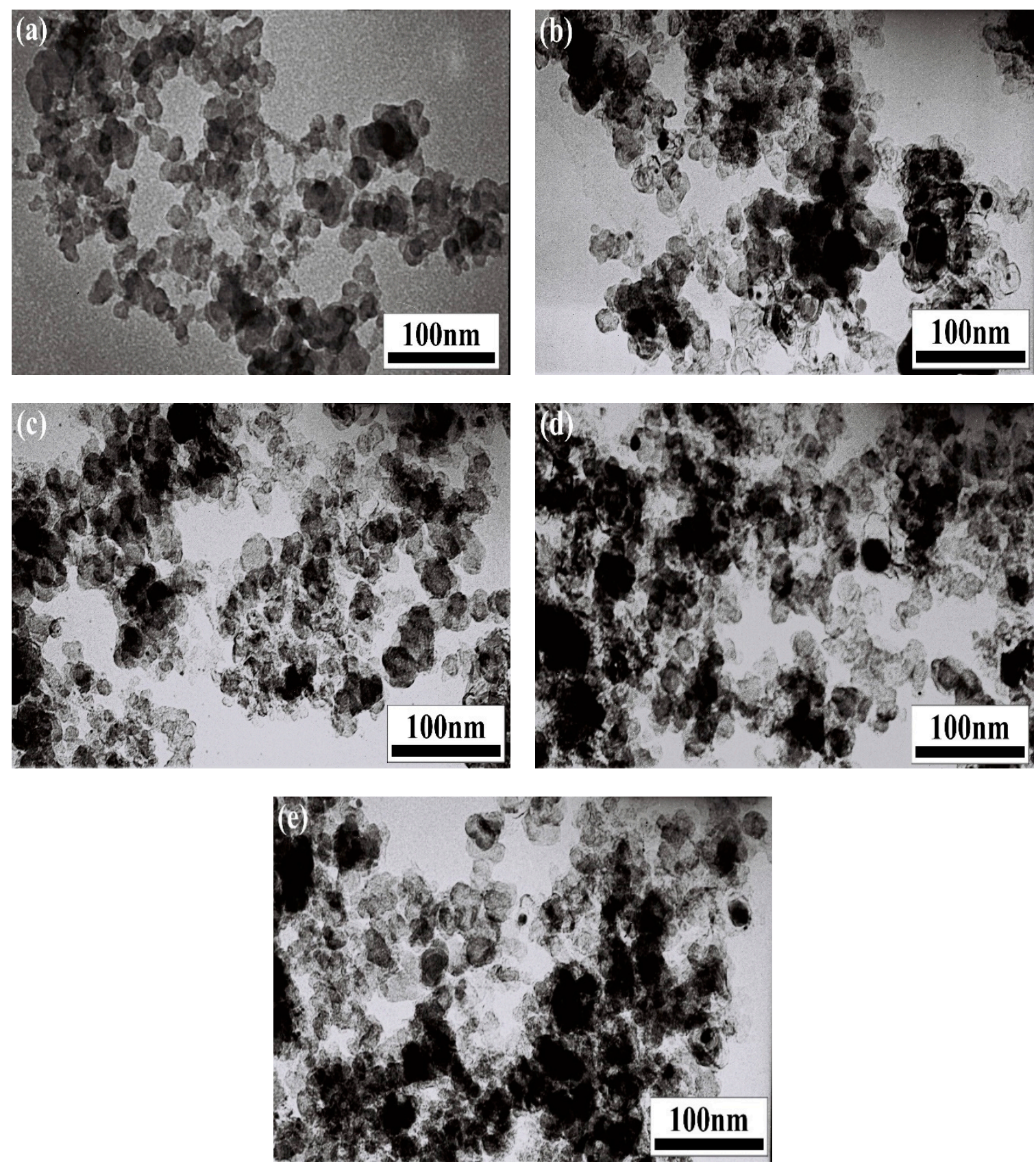

Figure 3. TEM micrographs of the powders before and after microwave heating: (a) before microwave heating; (b) $0.5 \mathrm{~h}$; (c) $1 \mathrm{~h}$; (d) $1.5 \mathrm{~h}$; (e) $2 \mathrm{~h}$.

To determine the effect of gamma irradiation on the microstructure of the synthesized nanopowders, XRD, TEM, and XPS measurements were carried out on the samples prepared by the microwave heating method at $1000{ }^{\circ} \mathrm{C}$ for $1 \mathrm{~h}$ in argon gas atmosphere, as shown in Figures 4-7. Figure 4 shows the XRD patterns of the powders $\left(1000^{\circ} \mathrm{C}, 1 \mathrm{~h}\right)$ before and after gamma ray irradiation. The insertion in Figure 4 is an enlargement of the diffraction peaks of the products at $38-40^{\circ}$. As shown in Figure 4, the products were mainly composed of $\mathrm{Cr}_{3} \mathrm{C}_{2}$ (JCPDS 35-0804) and $\mathrm{Cr}_{7} \mathrm{C}_{3}$ (JCPDS 11-0550), indicating that the phase compositions of the samples before and after gamma irradiation did not changed. According to the Scherrer equation [23], the average crystallite sizes of the powders before and after gamma irradiation were $26 \mathrm{~nm}$ and $35 \mathrm{~nm}$, respectively. This indicates that gamma irradiation can promote the growth of carbide grains. Comparing the peaks in the insertion in Figure 4, it can be seen that the diffraction peaks of $\mathrm{Cr}_{3} \mathrm{C}_{2}$ after irradiation with $150 \mathrm{kGy}$ gamma ray shifted toward 
smaller angles. According to the Bragg equation $2 d \sin \theta=n \lambda$ ( $d$ is the crystalline interplanar spacing, $\theta$ is the Bragg angle, $n$ is an integer, $\lambda$ is the wavelength of a beam of X-rays incident on a crystal with lattice planes separated by the distance $d$ ), the diffraction angle decreased with the increase of crystalline interplanar spacing. Furthermore, the diffraction peaks of irradiated $\mathrm{Cr}_{3} \mathrm{C}_{2}$ had a lower intensity than the peaks of the unirradiated sample. These phenomena are proposed to be attributed to the conversion of gamma radiation energy to crystal lattice energy and the entry of a small amount of carbon atoms into the $\mathrm{Cr}_{3} \mathrm{C}_{2}$ lattice, which led to the increase of the crystalline interplanar spacing and the change of crystal structure of $\mathrm{Cr}_{3} \mathrm{C}_{2}$ [27]. They may also be due to the transformation of $\mathrm{Cr}^{3+}$ with small ionic radium $(0.61 \mathrm{~nm})$ into $\mathrm{Cr}^{2+}$ with larger ionic radium $(0.73 \mathrm{~nm}) \mathrm{during}$ the reduction of a small amount of residual $\mathrm{Cr}_{2} \mathrm{O}_{3}$ to $\mathrm{Cr}_{3} \mathrm{C}_{2}$. Similar phenomena have been observed in the literature $[28,29]$.

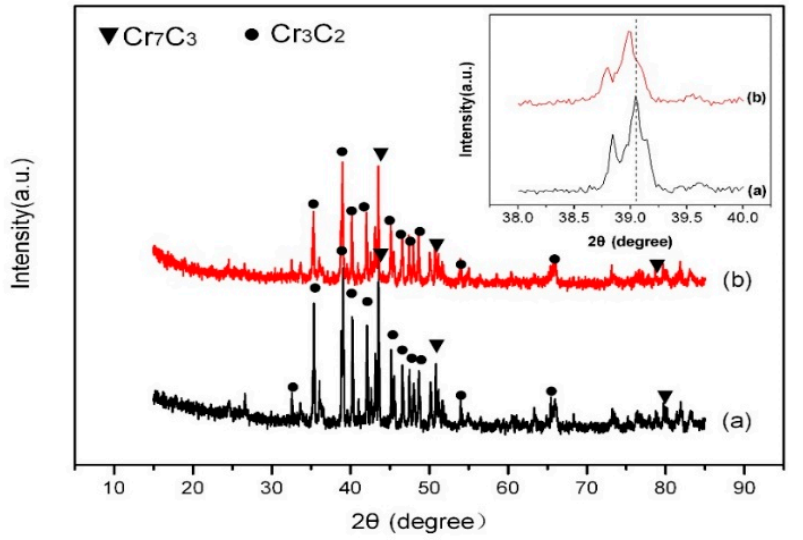

Figure 4. XRD patterns of the powders $\left(1000^{\circ} \mathrm{C}, 1 \mathrm{~h}\right)$ before and after gamma ray irradiation: (a) before gamma ray irradiation; (b) after gamma ray irradiation. The insertion is an enlargement of the diffraction peaks of the products at $38-40^{\circ}$.

Figure 5 shows the TEM and HRTEM images of the samples before and after gamma ray irradiation. As shown in Figure 5a, the powders before gamma ray irradiation showed good dispersion and were mainly composed of particles with a mean diameter of about $50 \mathrm{~nm}$. The selected area's electron diffraction (SAED) pattern in Figure 5a clearly shows the presence of diffraction dots, which indicates that the selected area presented a single-crystal nature. However, as shown in Figure $5 c$ some of the atoms were arranged irregularly. This was mainly due to the fact that $\mathrm{Cr}_{3} \mathrm{C}_{2}$ (JCPDS 35-0804) is a substoichiometric carbide [30]; it belongs to the orthorhombic system with ordered $C$ vacancies, and its lattice parameters are $0.5527 \mathrm{~nm} \times 1.1488 \mathrm{~nm} \times 0.2829 \mathrm{~nm}$. The interplanar spacing in Figure $5 c$ was calculated and resulted to be $0.3725 \mathrm{~nm}$, which is consistent with that of a (120) plane $(\mathrm{d}=0.3704 \mathrm{~nm})$ of $\mathrm{Cr}_{3} \mathrm{C}_{2}$ (JCPDS 35-0804). Compared with Figure 5a, the powders after gamma ray irradiation showed obvious aggregation, and the particles appeared larger (Figure 5b). Furthermore, the SAED pattern in Figure 5b shows that the diffraction spots were irregularly distributed, and the crystal structure of $\mathrm{Cr}_{3} \mathrm{C}_{2}$ appeared changed, which was mainly caused by a small amount of carbon atoms entering empty spaces or to the transformation of small-radium ions to large-radium ions during the reduction of $\mathrm{Cr}_{2} \mathrm{O}_{3}$ to $\mathrm{Cr}_{3} \mathrm{C}_{2}$. These results are consistent with the XRD measurements (Figure 4). The interplanar spacing in Figure $5 \mathrm{~d}$ was calculated and the result was $0.3824 \mathrm{~nm}$, which is obviously higher than that obtained before gamma ray irradiation. Besides, the arrangement of atoms in Figure $5 d$ was more regular than that observed of Figure $5 c$. These phenomena are consistent with the results of SAED. 

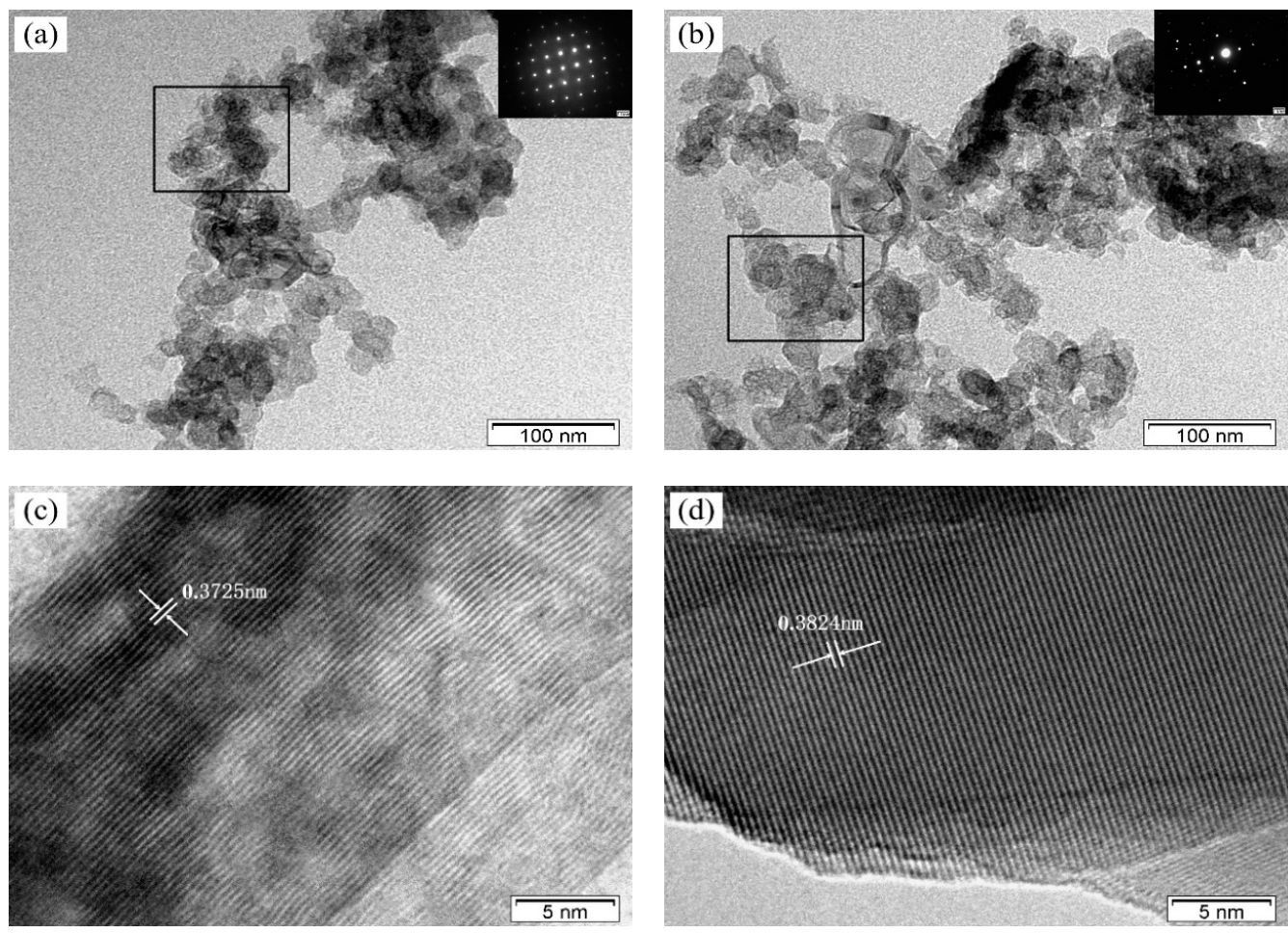

Figure 5. (a) TEM image of the sample before gamma ray irradiation; the inset shows the corresponding SAED pattern; (b) TEM image of the sample after gamma ray irradiation; the inset shows the corresponding SAED pattern; (c) HRTEM image of the sample before gamma ray irradiation; (d) HRTEM image of the sample after gamma ray irradiation.

Figure 6 shows the XPS spectra of the samples $\left(1000^{\circ} \mathrm{C}, 1 \mathrm{~h}\right)$ before and after gamma irradiation. As shown in Figure 6, the surface of the specimen was mainly composed of $\mathrm{Cr}, \mathrm{C}$, and $\mathrm{O}$. The peaks of $\mathrm{A}(576.1 \mathrm{eV} \rightarrow 577.4 \mathrm{eV})$ and $\mathrm{B}(577.6 \mathrm{eV} \rightarrow 587.3 \mathrm{eV})$ in Figure 7 were assigned to the $\mathrm{Cr} 2 \mathrm{p}_{3 / 2}$ species of $\mathrm{Cr}_{3} \mathrm{C}_{2-\mathrm{x}}(0 \leq \mathrm{x} \leq 0.5)$ and $\mathrm{Cr}_{2} \mathrm{O}_{3}$, respectively. Furthermore, the peaks of the irradiated sample shifted toward higher binding energy and became sharper compared to those of the unirradiated powders. These phenomena may be caused by the diffusion of carbon atoms from the surface to the interior after gamma irradiation, leading to the increase of the crystalline interplanar spacing and the change of the crystal structure of $\mathrm{Cr}_{3} \mathrm{C}_{2}$ [31]. These results are consistent with the XRD and TEM measurements (Figures 4 and 5). The higher binding energy improves the thermal stability and mechanical properties of $\mathrm{Cr}_{3} \mathrm{C}_{2}$ at high temperature.

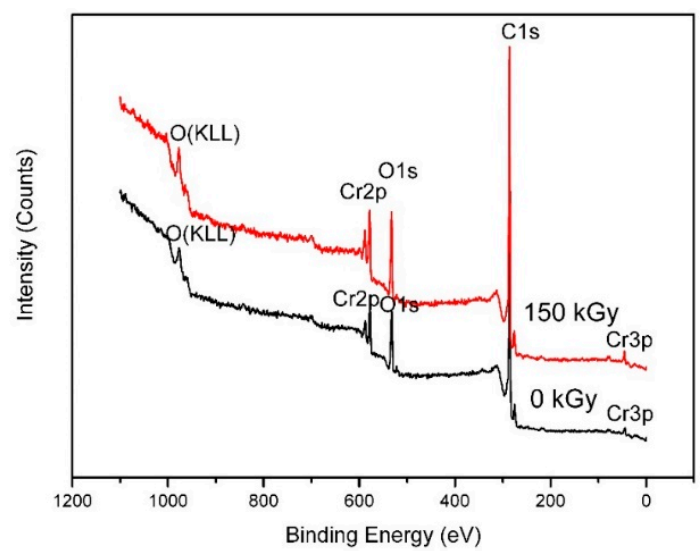

Figure 6. XPS spectra of the sample $\left(1000^{\circ} \mathrm{C}, 1 \mathrm{~h}\right)$ before and after gamma ray irradiation. 


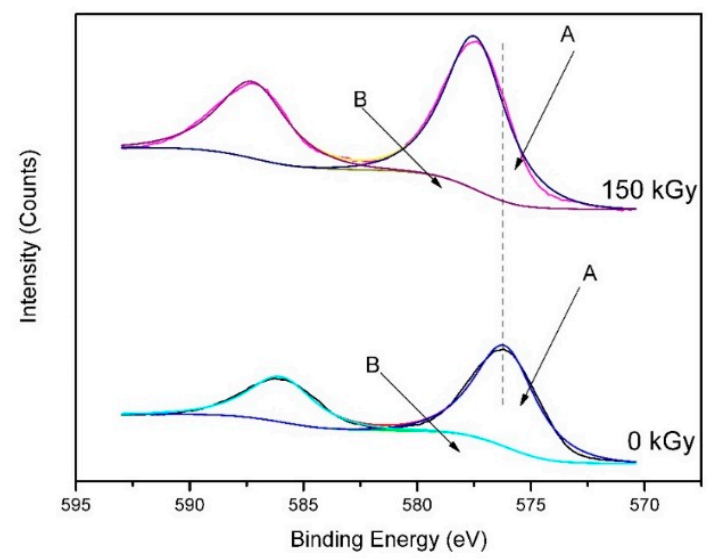

Figure 7. XPS spectrum of the Cr2p energy region for the powders $\left(1000{ }^{\circ} \mathrm{C}, 1 \mathrm{~h}\right)$ before and after gamma ray irradiation.

\section{Materials and Methods}

Micron-sized chromic oxide $\left(\mathrm{Cr}_{2} \mathrm{O}_{3}\right)$ and nano-sized carbon black were used as raw materials. We put $66 \mathrm{wt} \%$ ( $68 \mathrm{wt} \%$ ) $\mathrm{Cr}_{2} \mathrm{O}_{3}$ and $34 \mathrm{wt} \%$ (32 wt $\%$ ) C into a QM-3SP2 high-energy planetary ball mill (Nanjing Lai Technology Industrial Co., Ltd., Jiangsu, China). The mixing and milling medium were absolute alcohol and cemented carbide balls, respectively. After milling for $64 \mathrm{~h}$, the mixture was dried in a vacuum drying oven at $90{ }^{\circ} \mathrm{C}$ for $12 \mathrm{~h}$. Figure 8 shows SEM micrographs of the powders obtained before and after mechanical alloying $(34 \mathrm{wt} \% \mathrm{C})$. The powders before mechanical alloying were mainly composed of 1-2 $\mu \mathrm{m}$ and nano-sized particles (Figure 8a). The powders after mechanical alloying showed good dispersion and were mainly composed of spherical or nearly spherical particles with a mean diameter of about $100 \mathrm{~nm}$ (Figure 8b). Finally, the mixture was heated at $1000{ }^{\circ} \mathrm{C}$ for different holding time $(0.5 \mathrm{~h}, 1 \mathrm{~h}, 1.5 \mathrm{~h}$, and $2 \mathrm{~h})$ at a heating rate of $15-50{ }^{\circ} \mathrm{C} / \mathrm{min}$ in a multimode 2.45 GHz RWS microwave furnace (Zhongsheng Thermal Technology Co., Ltd., Hunan, China) in argon gas atmosphere to prepare $\mathrm{Cr}_{3} \mathrm{C}_{2}$ nanopowders. During microwave heating, $900-1100 \mathrm{~W}$ power was applied to the samples, and the temperature was measured by infrared measurement (Raytek Inc., Santa Cruz, CA, USA).
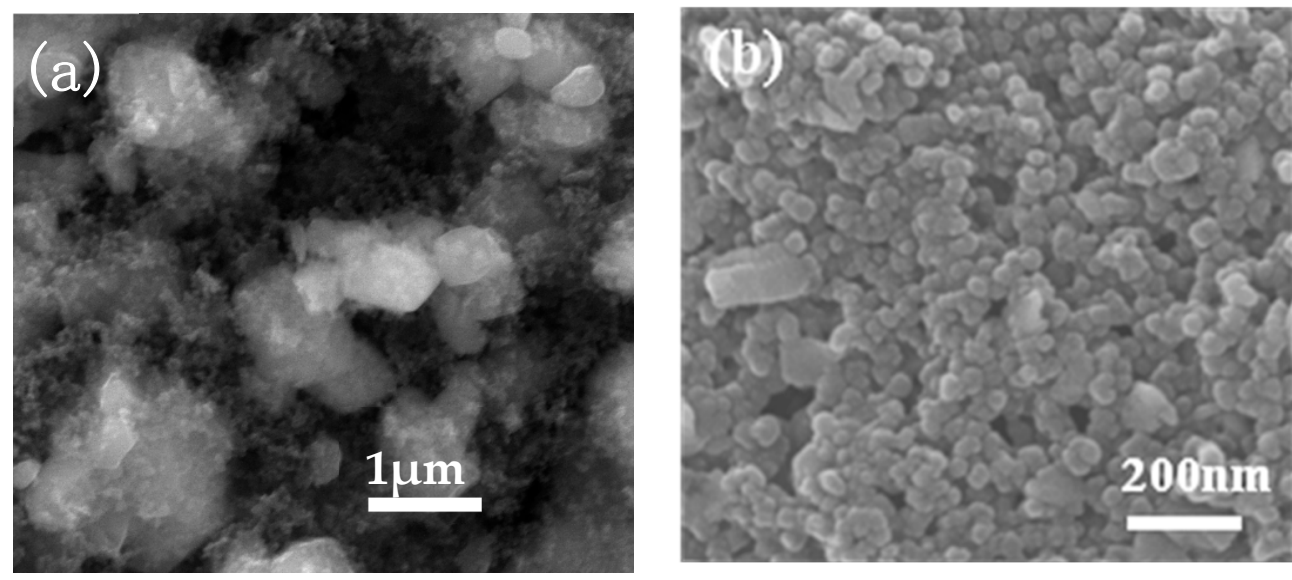

Figure 8. SEM micrographs of the powders obtained before and after mechanical alloying: (a) before mechanical alloying; (b) after mechanical alloying.

The samples were irradiated under gamma $\left({ }^{60} \mathrm{Co}\right.$ source) radiation in a radiation chamber with a dose rate of $100 \mathrm{~Gy} / \mathrm{min}$ at an absorbed dose of $150 \mathrm{kGy}$. The crystal structure of the samples was analyzed by X-ray diffraction (XRD) using a Bruker D8 Advance diffractometer ( Bruker AXS Inc., Karlsruhe, Germany) with $\mathrm{Cu}-\mathrm{K}_{\alpha}$ radiation in the range of $2 \theta=15$ to $85^{\circ}$. X-ray 
photoelectron spectroscopy (XPS) was carried out using a XSAM 800 spectrometer (Kratos Analytical, Manchester, UK) with MgK ( $\alpha 1)$ X-ray source. The morphology and microstructure of the samples were examined by JSM-6700F scanning electron microscopy (SEM), JEM-1000CX, and JEM-2100 transmission electron microscopy (TEM) (JEOL Ltd., Tokyo, Japan).

\section{Conclusions}

$\mathrm{Cr}_{3} \mathrm{C}_{2}$ nanopowders were synthesized via mechanical alloying and subsequent microwave heating. The powders prepared at $1000{ }^{\circ} \mathrm{C}$ for $1 \mathrm{~h}$ showed good dispersion and were mainly composed of spherical or nearly spherical particles with a mean diameter of about $50 \mathrm{~nm}$. The synthesis temperature required by the presented method was at least $400{ }^{\circ} \mathrm{C}$ lower than that of conventional methods. Shorter holding time led to the appearance of oxides and agglomeration. On the contrary, longer holding time led to the increase of crystalline interplanar spacing of the carbide and the occurrence of molten particles. Gamma ray irradiation had an important effect on the microstructure of $\mathrm{Cr}_{3} \mathrm{C}_{2}$ nanopowders. XRD, HRTEM, and XPS results showed that gamma ray irradiation can increase the crystalline interplanar spacing and the binding energy of $\mathrm{Cr}_{3} \mathrm{C}_{2}$, which improves the thermal stability and mechanical properties of $\mathrm{Cr}_{3} \mathrm{C}_{2}$ at high temperature. Besides, gamma ray irradiation can also lead to the increase of the crystalline interplanar spacing and the change of the crystal structure of $\mathrm{Cr}_{3} \mathrm{C}_{2}$.

Author Contributions: Conceptualization, Z.Z. and W.S.; Methodology, K.J., Z.Z., C.G. and Y.J;; Software, S.W. and K.J.; Validation, K.J., Y.J. and Z.Z.; Formal Analysis, Z.Z.; Investigation, K.J. and Z.Z.; Resources, Y.J., W.S. and Z.Z.; Data Curation, K.J., S.W. and Z.Z.; Writing-Original Draft Preparation, K.J. and Z.Z.; Writing-Review \& Editing, Z.Z., K.J. and C.G.; Visualization, S.W.; Supervision, S.W.; Project Administration, Z.Z.; Funding Acquisition, Z.Z. and C.G.

Funding: The research was supported by the Natural Science Foundation of China (51304063 and 21404032), the Program for Science \& Technology Innovation Talents in Universities of Henan Province (16HASTIT011), the Funding Scheme for Young Teachers of Henan University of Technology (2018-35), and the Key Scientific and Technological Project of Henan Province (182102210389), China.

Conflicts of Interest: The authors declare no conflict of interest.

\section{References}

1. Schwarzkopf, P.; Kieffer, R.; Leszynski, W.; Benesovsky, F. Refractory Hard Metals: Borides, Carbides, Nitrides, and Silicides; Macmillan: New York City, NY, USA, 1953.

2. James, F.S.; William, A. CRC Materials Science and Engineering Handbook, 3rd ed.; CRC Press: Boca Raton, FL, USA, 2001.

3. Kahrizsangi, R.E.; Zadeh, H.M.; Nemati, V. Synthesis of chromium carbide by reduction of chromium oxide with methane. Int. J. Refract. Met. Hard Mater. 2010, 28, 412-415. [CrossRef]

4. Haynes, W.M. (Ed.) CRC Handbook of Chemistry and Physics, 91st ed.; CRC Press/Taylor and Francis: Boca Raton, FL, USA, 2010.

5. Kang, Y.M.; Cui, X.W.; Dong, Z.Q.; Chen, W.X. Preparation, microstructure and properties of chromium carbide/epoxy composite. Mater. Design 2016, 92, 356-361. [CrossRef]

6. Boccarusso, L.; Scherillo, F.; Prisco, U. Effects of $\mathrm{Cr}_{3} \mathrm{C}_{2}$ Addition on Wear Behaviour of WC-Co Based Cemented Carbides. Metals 2018, 8, 895. [CrossRef]

7. Loubière, S.; Laurent, C.; Bonino, J.P.; Rousset, A. A metastable chromium carbide powder obtained by carburization of a metastable chromium oxide. J. Alloy. Compd. 1996, 243, 59-66. [CrossRef]

8. Hirota, K.; Mitani, K.; Yoshinaka, M.; Yamaguch, O. Simultaneous synthesis and consolidation of chromium carbides $\left(\mathrm{Cr}_{3} \mathrm{C}_{2}, \mathrm{Cr}_{7} \mathrm{C}_{3}\right.$ and $\left.\mathrm{Cr}_{23} \mathrm{C}_{6}\right)$ by pulsed electric-current pressure sintering. Mat. Sci. Eng. A 2005, 399, 154-160. [CrossRef]

9. Xing, T.Y.; Cui, X.W.; Chen, W.X.; Yang, R.S. Synthesis of porous chromium carbides by carburization. Mater. Chem. Phys. 2011, 128, 181-186. [CrossRef]

10. Koswon, K.; Shon, I.J. Synthesis of $\mathrm{Cr}_{3} \mathrm{C}_{2}$ by SHS process. Scr. Mater. 1997, 17, 889-895. [CrossRef] 
11. Dai, L.; Lu, Y.; Wang, X.Y.; Zhua, J.; Li, Y.H.; Wang, L. Production of nano-sized chromium carbide powders from $\mathrm{Cr}_{2} \mathrm{O}_{3} / \mathrm{C}$ precursors by direct electrochemical reduction in molten calcium chloride. Int. J. Refract. Met. Hard Mater. 2015, 51, 153-159. [CrossRef]

12. Sharafi, S.; Gomari, S. Effects of milling and subsequent consolidation treatment on the microstructural properties and hardness of the nanocrystalline chromium carbide powders. Int. J. Refract. Met. Hard Mater. 2012, 30, 57-63. [CrossRef]

13. Suryanarayana, C. Mechanical alloying and milling. Prog. Mater. Sci. 2001, 46, 1-184. [CrossRef]

14. Syazwan, M.M.; Azis, R.S.; Hashim, M.; Ismayadi, I.; Kanagesan, S.; Hapishah, A.N. Co-Ti-and Mn-Ti-substituted barium ferrite for electromagnetic property tuning and enhanced microwave absorption synthesized via mechanical alloying. J. Aust. Ceram. Soc. 2017, 53, 465-474. [CrossRef]

15. Zhao, C.N.; Zhang, J.J.; Li, Y.; Meng, X.; Li, H.B. Microwave-assisted extraction of phenolic compounds from melastoma sanguineum fruit: Optimization and identification. Molecules 2018, 23, 2498. [CrossRef] [PubMed]

16. Gunnewiek, R.F.K.; Kiminami, R.H.G.A. Fast synthesis of porous chromium carbide by microwave-assisted carbothermal reduction. Ceram. Int. 2017, 43, 10614-10618. [CrossRef]

17. Silambarasan, D.; Surya, V.J.; Iyakutti, K.; Asokanf, K.; Vasu, V.; Kawazoe, Y. Gamma ( $\gamma$ )-ray irradiated multi-walled carbon nanotubes (MWCNTs) for hydrogen storage. Appl. Surf. Sci. 2017, 418, 49-55. [CrossRef]

18. Maity, T.K.; Sharma, S.L.; Chourasiya, G. The real-time gamma radiation dosimetry with $\mathrm{TeO}_{2}$ thin films. Radiat. Meas. 2012, 47, 145-148. [CrossRef]

19. Safibonab, B.; Reyhani, A.; Nozad Golikand, A.; Mortazavi, S.Z.; Mirershadi, S.; Ghoranneviss, M. Improving the surface properties of multi-walled carbon nanotubes after irradiation with gamma rays. Appl. Surf. Sci. 2011, 258, 766-773. [CrossRef]

20. Soleimanpour, A.M.; Hou, Y.; Jayatissa, A.H. The effect of UV irradiation on nanocrysatlline zinc oxide thin films related to gas sensing characteristics. Appl. Surf. Sci. 2011, 257, 5398-5402. [CrossRef]

21. Kleut, D.; Jovanovic, S.; Markovic, Z.; Kepic, D.; Tosic, D.; Romcevic, N. Comparison of structural properties of pristine and gamma irradiated single-wall carbon nanotubes: Effects of medium and irradiation dose. Mater. Charact. 2012, 72, 37-45. [CrossRef]

22. Naim, A.A.; Alnaim, N.; Ibrahim, S.S.; Metwally, S.M. Effect of gamma irradiation on the mechanical properties of PVC/ZnO polymer nanocomposite. J. Radiat. Res. 2017, 10, 165-171. [CrossRef]

23. Matyi, R.J.; Schwartz, L.H.; Butt, J.B. Particle size, particle size distribution, and related measurements of supported metal catalysts. Catal. Rev. Sci. Eng. 1987, 29, 41-99. [CrossRef]

24. Zhao, Z.W.; Zheng, H.J.; Wang, Y.; Mao, S.; Niu, J.; Chen, Y.; Shang, M.Y. Synthesis of chromium carbide $\left(\mathrm{Cr}_{3} \mathrm{C}_{2}\right)$ nanopowders by the carbonization of the precursor. Int. J. Refract. Met. Hard Mater. 2011, $29,614-617$. [CrossRef]

25. Zhao, Z.W.; Zheng, H.J.; Zhang, S.; Song, W.; Mao, S.; Chen, Y. Effect of reaction time on phase composition and microstructure of chromium carbide nanopowders. Int. J. Refract. Met. Hard Mater. 2013, 41, 558-562. [CrossRef]

26. Gogebakan, M.; Kursun, C.; Eckert, J. Formation of new Cu-based nanocrystalline powders by mechanical alloying technique. Powder Technol. 2013, 247, 172-177. [CrossRef]

27. Abbas, I.K.; Najam, L.A.; AuobSulaiman, A.U. The effect of gamma irradiation on the structural properties of porous silicon. Int. J. Phys. 2015, 3, 1-7. [CrossRef]

28. Mahajan, M.; Rajpoot, S.; Pandey, O.P. In-situ synthesis of chromium carbide $\left(\mathrm{Cr}_{3} \mathrm{C}_{2}\right)$ nanopowders by chemical-reduction route. Int. J. Refract. Met. Hard Mater. 2015, 50, 113-119. [CrossRef]

29. Zhao, Z.W.; Zheng, H.J.; Liu, S.J.; Shen, J.H.; Song, W.Q.; Chen, J.S. Low temperature synthesis of chromium carbide $\left(\mathrm{Cr}_{3} \mathrm{C}_{2}\right)$ nanopowders by a novel precursor method. Int. J. Refract. Met. Hard Mater. 2015, 48, 46-50. [CrossRef] 
30. Preiss, H.; Schultzeb, D.; Szulzewsky, K. Carbothermal synthesis of vanadium and chromium carbides from solution-derived precursors. J. Eur. Ceram. Soc. 1999, 19, 187-194. [CrossRef]

31. Rai, V.N.; Raj Shekhar, B.N.; Kher, S.; Deb, S.K. Effect of gamma ray irradiation on optical properties of $\mathrm{Nd}$ doped phosphate glass. J. Lumin. 2010, 130, 582-586. [CrossRef]

Sample Availability: Samples of the compounds are not available from the authors.

(C) 2018 by the authors. Licensee MDPI, Basel, Switzerland. This article is an open access article distributed under the terms and conditions of the Creative Commons Attribution (CC BY) license (http:/ / creativecommons.org/licenses/by/4.0/). 